\title{
FINANCIAL PERFORMANCE ANALYSIS TO PUBLIC INSTITUTIONS
}

\author{
Teodor Hada \\ Nicoleta Bărbuță-Mișu ${ }^{2}$ \\ Mihai Cărut \\ Teodora Maria Avram ${ }^{4}$
}

\begin{abstract}
Performance is a permanent concern of all economic and non-economic actors participating in the financial circuit. Public sector performance describes the results of an activity in a given area, the cumulative results or all areas of activity of a public body, measured either in absolute terms or in relation to the results obtained in previous periods. Establishing a level of performance in the public sector at the institution level is a continuous and systematic process of measuring and evaluating own products, services and practices, comparing them with the best products of prestigious organizations in the same field. The paper approaches public institutions and their particularities, the performance concept in general and public institutions performance in particular. Also, the structure of the account of patrimonial result of public institutions is analysed and the patrimonial result is proposed as performance indicator to public institutions. Finally, the paper present a case study related to the financial performance analysis to a public institution - City Hall.
\end{abstract}

Keywords: financial performance, public sector, public institution, patrimonial result

JEL Classification: $H 70, H 83$

\section{Introduction}

The performance can be defined in multiple ways, namely: success, result of the action and the action (Bourguignon, 1995). The success, expressing the success of a business, is a very general notion, which can be attributed to several favourable conditions, since it is difficult to identify a single result for its measurement. Success is the reason we could say that performance does not exist in itself, because it varies according to goals and objectives set by each organization. The second meaning attributed to performance, the result of the action, it only embraces the value. The performance is the result of a process or activity. According to the third sense, performance is not only the result measured at the end of a transaction but the whole process of obtaining performance.

Thus, Pintea (2011) explains the diverse visions of defining the concept of performance through the stages of the evolution of the concept of performance:

- the 1950-1980 period, when there is no homogeneity in the definition of this concept and a variety of performance assessment criteria are used, among which: productivity, flexibility, adaptability, capacity, environmental control, turnover, production costs, etc.;

- the end of the 1980-1990 period, in which the performance was defined according to the level of achievement of the objectives;

\footnotetext{
${ }^{1}$ Professor PhD., "Bogdan Vodă” University Cluj-Napoca, Email: teohada@yahoo.com

${ }^{2}$ Professor PhD, "Dunarea de Jos" University of Galati, Email: nicoleta.barbuta@ugal.ro

${ }^{3}$ PhD Student, "1 Decembrie 1918” University Alba Iulia, Email: mihaimihnea@gmail.com

${ }^{4}$ PhD Student, “1 Decembrie 1918” University Alba Iulia, Email: avram_teodora@ymail.com

DOI: 10.29302/oeconomica.2017.19.2.4
} 
- the period 1995-2000, when the performance was defined according to the efficiency and effectiveness of the enterprise;

- $\quad$ after 2000, when performance is defined according to value creation, subordinated to the goal of sustainable development (Niculescu, 2003).

From the practical activity can be revealed some defining elements of performance, which are mostly based on the evaluation of a man, process, machine, phenomenon or state of matter. Thus, performance occurs in a well-defined space and time, it is equal to the best result obtained in a competition, allows a hierarchy of values after qualitative or quantitative determinations, and there is a permanent relationship between motor performance and cognitive and intellectual component (Oprea, 2011).

Due to the complexity of the term of performance, in order to understand the strict meaning of the specific word to the field we refer to, it is desirable to study performance according to the field of interest and activity of the institution, which is why we present various forms of performance. Thus, the paper is organized as follows: section 2 highlight economic and financial performance, section 3 presents public institutions, their particularities and performance, section 4 presents the methodology and data analysed for assessing public institution performance, continuing with results in section 5 and final conclusions in the section 6 .

\section{Economic and financial performance}

It is difficult to define the concept of performance (Cardos and Mut, 2012) considering the variety of keywords assigned to it. Thus, economic performance is the level at which an industry reaches the goals or objectives pursued by companies operating within it. Performance is multidimensional, covering aspects of profitability, innovation, product design, quality and growth (Sava, 1999). The enterprise's performance reflects the ability of the entity's resources to generate future cash flows and the efficiency with which they are used (Mates et al., 2006).

In the literature, the two major variables of performance are often met, namely: effectiveness and efficiency. While effectiveness reflects the extent to which external users' expectations (such as shareholders, customers, state, suppliers, employees) are met, efficiency is measured by the degree of meeting the expectations of the company's internal environment (Buse, 2005). The purpose of performance is to achieve the objectives set by the company's guidelines, and it does not just appear to find a product, but rather is the result of comparisons and goals (Noyer, 2002).

The performance of an entity depends on its working teams and by a professional management, who is recommended to continuously participate in training programs (Chiriac, 2014). Being a complex concept, performance shows the position of an entity in the competitive environment and can be measured with various economic and financial indicators (Hada, 2010). At the same time, performance is an economic and financial security for any company that achieve it, which can lead to its development and modernization due to a stability found by shareholders or associates.

The performance is represented by that level of the best results achieved (Barbulescu and Bagu, 2001) and the global performance is the ability of the firm to create value for all its stakeholders, i.e. shareholders, creditors, employees, suppliers, the local community, etc. (Tabara and Dicu, 2007). Also, from an economic perspective, the concept of performance covers different concepts, but the most important indicators are considered: profitability, yield, productivity and efficiency (Colasse, 1999).

A high-performing company is an enterprise that creates value for shareholders, satisfying customers, which takes into account the views of its employees and respects the natural environment. Thus the shareholder is satisfied because the company has achieved the 
desired profitability, customers are confident in the future of the enterprise and the quality of its products and services, the employees are proud of the enterprise they work in and the society enjoys the company's environmental protection policy (Jianu, 2007).

Economic performance is closely related to financial performance, and so the concept of economic-financial performance (Bistriceanu, 2001) was born, being defined as that superior quality level of economic and financial activity carried out by economic agents, which is appreciated by several indicators, as are: turnover, return on capital, labour productivity, gross and net profit, annual rate of renewal of fixed capital, fixed asset efficiency, etc.

Economic performance is associated with the term of performance management that has as the primary goal improving economic results with maximum efficiency and effectiveness. The results obtained depend on all the factors involved in the activity developed, as well as the human factors with material resources.

Financial performance (Dumitrascu and Dumitrascu, 2003) expresses synthetically the quantitative and qualitative aspects of the economic activity of the company. The enterprise's goal is to release economic surpluses in relation to the recorded resources consumption. For this reason, measuring and analysing financial performance is an important dimension of the financial diagnosis and implicitly of the financial management of the enterprise.

The most well-known specific indicators and models for financial performance analysis at entity level are mainly based on the Profit and Loss Account and the profitability rates.

\section{Performance to public institutions}

Public institutions are defined as non-profit state entities comprising: the Romanian Parliament, the Romanian Presidency, the Government of Romania, the Ministries, the other specialized bodies of the public administration, the Judicial Authority as well as state institutions of central and local subordination, regardless of how they finance their activity (Bistriceanu, 2001). Public institutions are those institutionalized economic units whose primary function is to redistribute income and wealth on services provided to the public, in cases where companies do not offer such services on the market or offer them in insufficient quantities (Morariu, 2004).

The peculiarities of the public institutions derive from the specifics of their activity, from the way of financing, from the legal status, being given by the law of establishing the institution to the task of their leaders, who fulfil the capacity of authorizing officers (Morariu, 2004). Public institutions are units that generally do not carry out productive activities, but activities of leadership, guidance, coordination and control in the field of state administration and provide services with certain social functions in the sphere of social-cultural actions, justice, prosecution and defending of the country.

The expenditure on maintenance, operation and investments, as well as those for the performance of services by public institutions are financed from the state budget or from local budgets in the form of budget credits. Some public institutions that make revenues from different taxes, rents or services provide income to the budget they are funded from. Other categories of public institutions have their own income base which allows them to cover themselves by self-financing a part of the volume of expenditure, receiving in addition funds from the budget.

Public institutions have the following features that distinguish them from economic agents (Raduti, 2003):

- are patrimonial units of the State law that carry out political or executive activity, representing power and administration in society; 
- the patrimony of the public institution is attributed to its establishment by Government Laws and Decisions by its delimitation of the public and private patrimony of the state or of the administrative-territorial units. If economic agents create their wealth on the basis of the subscribed capital paid by investors, the economic capital category does not intervene in public institutions;

- the public institutions have limited legal personality, according to the act of establishment and the degree of hierarchical subordination;

- leaders of public institutions empowered to manage budgetary resources have the status of credit ordinators;

- the current and capital expenditures of the public institution and the services provided are funded in the form of budgetary credits, as follows:

subordination; entirely from the state budget or local budgets, depending on

- from extra-budgetary revenues and allocations granted by the state budget or local budgets, depending on subordination;

- $\quad$ entirely from extra-budgetary income;

- from special funds, through certain expenses established by law.

- public institutions making income from taxes or other sources have the obligation to pay them to the budget, or they benefit from these incomes in whole or in part, according to the legal provisions, as a source of self-financing of their activity;

- public institutions having as objectives providing the complete and high quality of public services without the pursuit of profit, in their management there are no financial results (profit or loss), these being non-profit units;

- the activity of public institutions does not fall within the scope of value added tax;

- the public institutions draw up the revenue and expenditure budget in accordance with the country's strategic economic and social development objectives and with the priorities set by the competent public authorities, budgets approved by the senior ordinators and monitoring their compliance with the expenditure limits, the way in which the various obligations towards the state are fulfilled, as well as the way the destinations of the provided financial resources are respected.

The communal bodies, represented by the communal, town and municipal councils, are the structures that realize the local autonomy and have as attributions the elaboration and approval of the annual draft of the local budget, the establishment of the local taxes and fees, as well as the special taxes, according to the law.

Public sector performance describes the results of an activity in a given area, aggregate results or all areas of activity of a public body, being measured either in absolute terms or in relation to the results obtained in previous periods (Handler, 2005). Establishing a level of performance in the public sector at the institution level is a continuous and systematic process of measuring and evaluating its own products, services and practices, comparing them with the best products of prestigious organizations in the same field (Abaluta, 2004).

In principle, there are a number of difficulties in the public sector in defining the notion of performance, which refers to: the sense of the concept of performance, the way to achieve performance, and identifying performance criteria and indicators, or, in other words, evaluating it.

Measurement of public sector performance involves taking into account the distinction between the following aspects that occur in a production process: the means used, the process, the product and the result or effect. From this perspective, we can establish a link between the public benefits and the means used to obtain them and between objectives achieved by these benefits (Profiroiu and Profiroiu, 2007). 
Smith (1983) believes that performance measurement can be effective in public sector entities if it is clearly understood what is being measured, which means that entities have clear objectives. He is adept at measuring performance through indicators, because they act as identifiers of areas where unusual performance can occur.

Another vision of the performance of public sector entities proposes its measurement through a set of indicators (Likierman, 1993). According to Likierman (1993), public sector performance indicators are valuable management tools only if they are used properly. Their values indicate whether or not resources are wasted, or whether management actions are appropriate. Based on research over three years and involving more than 500 mid-level and senior managers in public sector using performance indicators, Smith (1990) classifies the research results into four categories: concepts, preparation, implementation and use. At the same time, Likierman (1993) specifies the desired components and activities, which should be taken into account in each of the four groups when implementing performance indicators as managerial tools. He argues that these activities help the entity to adopt performance indicators for better outcomes and through the indicators system, the management actions can also be evaluated (Stefanescu et al., 2010).

From another point of view, Tripon et al. (2011) define performance measurement for public institutions as closely related to the purposes for which this type of measurement is used, or, more precisely, in relation to the usefulness or use of information on performance measurement. In this sense, we are considering that performance measurement for public institutions can be defined as: an instrument primarily designed for management, namely an informational system (gathering and analysis of information) useful for achieving managerial goals and objectives (decision-making, evaluation and monitoring of processes, increasing productivity, planning, establishing of resource allocation, motivation, strategy formulation, increasing and improving the quality of services provided, reform, increasing managerial accountability).

Regarding the reason of using performance measurement in public institutions, Behn (2003) considers that this type of measurement can serve multiple purposes depending on the different interests of both elected officials and citizens, or even managers and civil servants.

Table 1

Managerial goals of measuring performance in public institutions

\begin{tabular}{|c|c|}
\hline The purpose & $\begin{array}{r}\text { The public manager's question that the performance } \\
\text { measure can help answer }\end{array}$ \\
\hline To evaluate & How well is this public institution performing? \\
\hline To control & $\begin{array}{c}\text { How can public managers ensure their subordinates are doing } \\
\text { the right thing? }\end{array}$ \\
\hline To budget & $\begin{array}{c}\text { On what programs, people, or projects should public institution } \\
\text { spend the public's money? }\end{array}$ \\
\hline To motivate & $\begin{array}{c}\text { How can public managers motivate line staff, middle managers, } \\
\text { non-profit and for-profit collaborators, stakeholders, and } \\
\text { citizens to do the things necessary to improve performance? }\end{array}$ \\
\hline To promote & $\begin{array}{r}\text { How can public managers convince political superiors, } \\
\text { legislators, stakeholders, journalists, and citizens that their } \\
\text { public institution is doing a good job? }\end{array}$ \\
\hline To celebrate & $\begin{array}{c}\text { What accomplishments are worthy of the important } \\
\text { organizational ritual of celebrating success? }\end{array}$ \\
\hline To learn & Why is what working or not working? \\
\hline To improve & What exactly should who do differently to improve \\
\hline
\end{tabular}




\section{Source: Behn, R. D. (2003) Why Measure Performance? Different Purposes Require Different Measures, Public Administration Review, vol. 63, no. 5, pp. 586-606.}

Taking into account the limited approach of the notion of performance in the public sector entities in Romania, it is worth mentioning the proposal of a new facet of performance measurement in the public sector institutions, namely coercive performance (Stefanescu et al., 2010). The authors defined this type of performance as the extent to which the value restriction of a type of budget revenue $\mathrm{X}$ leads to the emergence / increase of a category of extra-budgetary income or to the restraint of the institution's activity. We appreciate that the use of this approach by actors involved in evaluating existing performance in public sector entities would be of interest, especially in the context of the mutations in the field, against the backdrop of the economic crisis (Stefanescu et al., 2010).

In Romania, public sector performance studies are still at an early stage, and the application of the concept of performance in practice is almost non-existent. Also, in Romania, there is currently no system for measuring the performance in the public space and no implementation and monitoring process. In many countries around the world, measuring the performance of the public sector, such as the USA, Canada, UK, Australia, New Zealand and Netherlands, performance measurement has become a practice adopted by law. China has begun to introduce a performance management system since the $1980 \mathrm{~s}$, which has been improved over the years. Therefore, we believe that it is necessary to identify the current methods of measuring the performance of the public sector at international level, contributing by delivering practical and original solutions to the improvement of the public sector performance in Romania (Mihaiu, 2014).

Consequently, we can say that the performance of public institutions is widely discussed in the literature, but to date there has been no common point of view, in that its definition has not received a unanimous connotation. The company's performance appraisal is much debated in the field of financial analysis. It can be said that the financial analysis proposes a partial diagnosis of performance and risk that only appears to be restrictive, given that it misses its own assumptions and limits in its area of investigation (Barbuta-Misu, 2009).

Performance is a permanent concern of all economic and non-economic actors participating in the financial circuit. The interest in measuring the company's financial performance, its measurement tools are closely related to the objectives of the firm and its partners: shareholders are concerned about their return on investment, employees are interested in firm stability and labour productivity, creditors follow the firms' solvency, providers are interested in perenniality of the business and of the markets on which it operates.

\section{Methodology and data}

For assessing the financial performance in public institutions we propose using the patrimonial result. Thus, the patrimonial result of the local budget is an economic result and, in its determination, all revenues and expenditures registered by public institutions funded from the local budget are taken into account, regardless of whether the revenue has been received or the expenses paid.

The timing of recognition of expenses is:

- Staff costs: salaries in cash and in kind, bonuses, $13^{\text {th }}$ salary, their contributions, are recognized in the period in which the work was done. The due and unpaid entitlements related to the budget exercise are also included in the staff costs of the exercise. 
- Expenditures with inventories are recognized when they have been consumed, except for the materials of the nature of inventory items that are recorded when they are disposed of.

- Goods costs include the consumption of inventories purchased and paid in previous budget years and consumed in the current budget exercise. Own consumption must be recorded at the time of production intended for this purpose.

- Service costs are recognized when the services were rendered and the works executed, regardless of when the payment was made.

- Interest costs are recognized as costs when they are due under the loan agreement and not when they are paid.

- Capital expenditures are recognized on a monthly basis in the form of depreciation that is recorded on a systematic basis over the useful life of the fixed asset.

The timing of recognition of income is:

- Revenues are recorded in the accounts of public institutions, on the basis of the documents evidencing the creation of the right of receivable (tax declaration or decision issued by the fiscal body), delivery notes, invoices, other legal documents drawn up or at the moment of their actual collection, when there are no prior documents for the registration of the claim.

- In accounting, incomes from economic activities are recorded when the goods are handed over to the buyers, delivered on the basis of the invoice or in other conditions stipulated in the contract, the invoicing of the executed works and the services rendered, the moment attesting the transfer of the property to the clients.

- The revenues of the public institutions come from rents, the organization of cultural and sporting events, artistic competitions, publications, editorial services, studies, projects, product valorisation from own activities or annexes, services and the like.

- Income from foreign exchange differences should be recognized in the period in which they arise on the settlement or reporting in financial statements of monetary items, receivables and payables at courses other than those initially recorded during the period or against those have been reported in the previous financial statements.

- Interest incomes are recorded as revenue when are generated.

Expense and income groups, presented in Annex 1, are detailed in synthetic accounts of grade I, II and III on Sector code, Funding source, Functional classification of income and expenses (chapter, subchapter, paragraph), and Economic classification of expenditures (title, article, paragraph).

For revenue collection, the account 521.01.00.02 „Available local budget" is used detailed on Funding source, and Functional classification of income. This account corresponds to the cashing from the treasury budget execution and is used only for cashing. The institution does not make payments from the daily receipts of the cash desk, first the money is deposited in the treasury and then withdrawn with a check for payments in the cash desk.

Income from taxes and duties based on tax decision or tax declaration is recorded at the beginning of the year, on total year, in the account 464.00.00 "Local budget claims", detailed on Financing Source, Functional classification of income. Tax declarations registered during the year enter to incomes in the following year.

The accounting records related to revenues to public institutions are as follows:

a. Registration of building tax revenues to individuals at the beginning of the year:

464.00.00.02.A.07020101 $=\frac{734.00 .00 .02 . \text { A.07020101 }}{}$ 
b. Registration of cashing of income from building tax:

$\overline{\text { 521.01.00.02.A.07020101 }}=\frac{\text { 464.00.00.02.A.07020101 }}{}$

c. Taxes that do not have a tax statement are recorded at the time of collection. For example, collection of construction authorization tax is recorded:

$\overline{\text { 521.01.00.02.A.160203 }}=\frac{735.06 .00 .02 . \mathrm{A} .160203}{}$

d. Grants, subsidies, transfers, budget allocations with special destination are recorded to incomes at the time of collection. For example, collecting amounts from the value added tax is recorded:

521.01.00.02.A.110206 $=\overline{735.02 .00 .02 . \mathrm{A} .110206}$

Incomes from economic activities are recorded at the time of invoicing and their cashing is done in the account 521.01.00.02.

Expenses are recorded when they are made and the payment is made from account 770.00.00 "Financing from the budget", detailed on the classification of expenses. The account 770.00 .00 is an account where only actual payments are recorded and it corresponds to payments from the treasury account. The account 770.00 .00 is not included in the calculation of the patrimonial result.

The accounting records related to expenses to public institutions are as follows:

a. Registration of the electricity expenses:

$\frac{610.00 .00 .02 . \mathrm{A} \cdot 51020103.200103}{4}=4$

b. Registration of the payment of the electricity expenses:

401.01.00.02.A.51020103.200103 $=\quad 770.00 .00 .02$. A.51020103.200103

The account 121 "Patrimonial result" closes quarterly and the debit balance expresses the patrimonial deficit and the credit balance expresses the patrimonial surplus.

At the end of the year, the budget execution result is drafted and it is actually the difference between the revenue received and the expenditure paid, i.e. the liquidities with which the institution closes the year. The available balance at the end of the year can be used in the next year only for investments and temporary coverage of house gaps. Then, there are closing the accounts 521.01.00.02 "Available from the local budget" and 770.00.00 "Financing from the budget" and the difference is transferred to account 521.02.00.02.A. "Results of budget execution from current year".

Data used in this paper belong to a City Hall. Quarterly data for closing the revenues and expenditure accounts are presented in the Annex 2. At the end of the financial year, after closing the revenues and expenditure accounts of the City Hall, the closure of the account 521.01.00 "Available from the local budget" is recorded as is presented in the Annex 3.

The operations related to determining the patrimonial result of the local budget for City Hall are: 
1. at the end of the quarter:

a. Closure of revenue accounts:

$7 \mathrm{xx}=121 \quad 1,322,978.28$

b. Closure of expense accounts:

$121=6 \mathrm{xx} \quad 682,127.81$

2. at the end of the financial year:

After closing the income and expenditure accounts, the following operations are performed:

a. Closing the account 521.01.00 "Available from the local budget", with the balance of local budget revenues in current year:

$521.02=521.01 .00 \quad 5,319,650.61$
allocated:

b. Taking over the payments made by the institutions to which credits have been

481.09.00.02.A. $=$

521.02.00.02.A.

$2.012 .577,64$

c. Closure of the account 770 "Financing from the budget" with the balance of net cash payments made from the local budget in the current year:

$\begin{array}{ll}\text { 770.00.00.02.A.xxxxxxxx } & \text { 521.02.00.02.A. 2,645,788.74 }\end{array}$

The closure of the account 770 "Financing from the budget" with the balance of net cash payments made from the local budget in the current year is presented in detail in Annex 4.

\section{Results}

Considering the quarterly data from the Annex 2 for City Hall, the data can be centralized in the account 121.00.00.02.A.A02 as follows:

\begin{tabular}{|c|c|}
\hline \multicolumn{2}{|c|}{ 121.00.00.02.A.A02 } \\
\hline $\mathrm{D}$ & $\mathrm{C}$ \\
\hline $682,127.81$ & $1,322,978.28$ \\
\hline & $640,850.47$ \\
\hline
\end{tabular}

The patrimonial result of the local budget of $640,850.47$ lei is an economic result and, in its determination, all revenues and expenditures registered by the institution financed from the local budget were taken into account, regardless of whether the revenues were received or the expenses paid.

Analysing the structure of the incomes that contributed to the achieving the patrimonial results we can see in table no. 2 that there are two important sources for quarterly 
incomes: sums deducted from VAT and quotas and amounts deducted from income tax with shares of $69.93 \%$ and respectively $20.60 \%$.

Table 2

The structure of quarterly incomes of City Hall

\begin{tabular}{|l|l|r|c|}
\hline $\begin{array}{c}\text { Code } \\
\text { account }\end{array}$ & \multicolumn{1}{|c|}{ Incomes } & \multicolumn{1}{|c|}{$\begin{array}{c}\text { Values } \\
\text { (RON) }\end{array}$} & \% \\
\hline 751.05 & $\begin{array}{l}\text { Voluntary transfers, other than subsidies (donations, } \\
\text { sponsorships) }\end{array}$ & 0 & - \\
\hline 751.03 & Fines, penalties and confiscations & $21,792.50$ & 1.65 \\
\hline 750.00 & Income from property & $12,170.00$ & 0.92 \\
\hline 739.00 & Other taxes and fees & 9.18 & 0.00 \\
\hline 735.06 & $\begin{array}{l}\text { Taxes on the use of the goods, the authorization of the } \\
\text { use of the goods or the carrying out of activities }\end{array}$ & 8476.26 & 0.64 \\
\hline 735.02 & Sums deducted from VAT & $925,215.00$ & 69.93 \\
\hline 734.00 & Taxes and fees on property & $75,309.58$ & 5.69 \\
\hline 732.01 & Other taxes on income, profit and capital gains & $7,530.00$ & 0.57 \\
\hline 731.02 & Quotas and amounts deducted from income tax & $272,475.76$ & 20.60 \\
\hline & Total incomes & $\mathbf{1 , 3 2 2 , 9 7 8 . 2 8}$ & $\mathbf{1 0 0 . 0 0}$ \\
\hline
\end{tabular}

Source: Data from City Hall presented in Annex 2

Analysing the structure of the expenditures we can see in table no. 3 that expenses affected patrimonial results are: expenditure on staff salaries with a share of $24.04 \%$, maintenance and repair costs with $20.28 \%$, social benefits with $11.69 \%$, other expenses authorized by legal provisions - current expenses with $9.44 \%$ and operating expenses related to the depreciation of fixed assets with $8.52 \%$.

Table 3

The structure of quarterly expenditures of City Hall

\begin{tabular}{|l|l|r|c|}
\hline $\begin{array}{c}\text { Code } \\
\text { account }\end{array}$ & \multicolumn{1}{|c|}{ Expenditures } & \multicolumn{1}{|c|}{$\begin{array}{c}\text { Values } \\
\text { (RON) }\end{array}$} & $\%$ \\
\hline 681.01 & Operating expenses related to the depreciation of fixed assets & $58,121.68$ & 8.52 \\
\hline 679.00 & Other expenses & $4,676.00$ & 0.69 \\
\hline 677.00 & Social benefits & $79,751.00$ & 11.69 \\
\hline 645.05 & Employer's contributions for leave and allowances & $1,395.00$ & 0.20 \\
\hline 645.04 & $\begin{array}{l}\text { Employers' contributions to work accidents and occupational } \\
\text { diseases }\end{array}$ & 246.00 & 0.04 \\
\hline 645.03 & Employer contributions for health insurance & $8,547.00$ & 1.25 \\
\hline 645.02 & Contributions of employers for unemployment insurance & 821.00 & 0.12 \\
\hline 645.01 & Contributions of employers for social insurance & $25,900.00$ & 3.80 \\
\hline 641.00 & Expenditure on staff salaries & $163,968.00$ & 24.04 \\
\hline 629.01 & $\begin{array}{l}\text { Other expenses authorized by legal provisions - current } \\
\text { expenses }\end{array}$ & $64,373.99$ & 9.44 \\
\hline 628.00 & Other expenditure with services performed by third parties & $39,186.69$ & 5.74 \\
\hline 626.00 & Postage and telecommunication charges & $5,783.90$ & 0.85 \\
\hline 614.00 & Expenditure on travel, postings, transfers & $2,658.00$ & 0.39 \\
\hline 611.00 & Maintenance and repair costs & $138,340.56$ & 20.28 \\
\hline 610.00 & Expenditure on energy and water & $44,451.06$ & 6.52 \\
\hline 602.08 & Expenditure on other consumables & $31,112.13$ & 4.56 \\
\hline
\end{tabular}




\begin{tabular}{|l|l|r|c|}
\hline 602.02 & Fuel costs & $12,795.80$ & 1.88 \\
\hline & Total expenses & $\mathbf{6 8 2 , 1 2 7 . 8 1}$ & $\mathbf{1 0 0 . 0 0}$ \\
\hline
\end{tabular}

Source: Data from City Hall presented in Annex 2

Analysing annual data of patrimonial result achieved by City Hall in the last five years (2012-2016) presented in Annex 5 we can conclude that (table no. 4):

- in total income, the high share is recorded by operating income (with shares between $97.47 \%$ in 2016 and $100 \%$ in 2012). If in the period 2012-2013 the high share in operating income was found to Funding, subsidies and transfers $(67.46 \%-73.16 \%)$, then in the period 2014-2016 the high share was recorded by Income from taxes, fees, contributions, insurance and other income of budgets, which show some changes in fiscal policy of collecting taxes;

- in total expenditure, the operating expenditure recorded a share of $100 \%$, except year 2013 when the share is $99.64 \%$. In operating expenditure, in the period 2012-2013 and 2016, the highest share was recorded by Capital expenditures, depreciation and provisions such as $63.32 \%, 75.24 \%$ and $46.11 \%$ when City Hall made investments; in the period 20142015, the high shares are found to Salaries and social contributions related to employees $(42.19 \%$ and $45.11 \%)$, and Inventories, consumables, works and services performed by third parties $(42.45 \%$ and $42.97 \%)$.

The structure of patrimonial result account in the period 2012-2016

\begin{tabular}{|c|l|c|c|c|c|c|}
\hline No. & \multicolumn{1}{|c|}{ Name of the indicator } & $\mathbf{2 0 1 6}$ & $\mathbf{2 0 1 5}$ & $\mathbf{2 0 1 4}$ & $\mathbf{2 0 1 3}$ & $\mathbf{2 0 1 2}$ \\
\hline I. & OPERATING INCOME & & & & & \\
\hline 1 & $\begin{array}{l}\text { Income from taxes, fees, } \\
\text { contributions, insurance and other } \\
\text { income of budgets }\end{array}$ & 83.73 & 61.47 & 64.50 & 21.40 & 27.89 \\
\hline 2 & Income from economic activities & 0.79 & 0.35 & 0.74 & 2.37 & 2.05 \\
\hline 3 & Funding, subsidies, transfers & 6.92 & 33.94 & 26.28 & 73.16 & 67.46 \\
\hline 4 & Other operating revenues & 7.03 & 4.16 & 8.41 & 3.04 & 2.60 \\
\hline & TOTAL OPERATING INCOME & 98.47 & 99.92 & 99.93 & 99.97 & 100.00 \\
\hline II. & OPERATING EXPENDITURE & & & & & \\
\hline 1 & $\begin{array}{l}\text { Salaries and social contributions } \\
\text { related to employees }\end{array}$ & 29.07 & 45.11 & 42.19 & 10.22 & 15.09 \\
\hline 2 & Subsidies and transfers & 4.34 & 11.22 & 14.27 & 2.54 & 4.64 \\
\hline 3 & $\begin{array}{l}\text { Inventories, consumables, works } \\
\text { and services performed by third } \\
\text { parties }\end{array}$ & 20.47 & 42.97 & 42.45 & 11.63 & 16.95 \\
\hline 4 & $\begin{array}{l}\text { Capital expenditures, depreciation } \\
\text { and provisions }\end{array}$ & 46.11 & 0.71 & 1.09 & 75.24 & 63.32 \\
\hline 5 & Other operating expenses & & & & & \\
\hline & $\begin{array}{l}\text { TOTAL OPERATING } \\
\text { EXPENSES }\end{array}$ & 100.00 & 100.00 & 100.00 & 99.64 & 100.00 \\
\hline IV. & FINANCIAL INCOME & - & - & - & - & - \\
\hline V. & FINANCIAL EXPENDITURE & - & - & - & 0.36 & - \\
\hline VIII. & EXTRAORDINARY INCOME & 1.53 & 0.08 & 0.07 & 0.03 & 0.00 \\
\hline IX. & $\begin{array}{l}\text { EXTRAORDINARY } \\
\text { EXPENDITURE }\end{array}$ & - & - & - & - \\
\hline & & & & & \\
\hline
\end{tabular}




\begin{tabular}{|l|l|l|l|l|l|l|}
\hline & TOTAL INCOME & 100.00 & 100.00 & 100.00 & 100.00 & 100.00 \\
\hline & TOTAL EXPENDITURE & 100.00 & 100.00 & 100.00 & 100.00 & 100.00 \\
\hline
\end{tabular}

Source: Data from City Hall presented in Annex 5

This analysis shows a fluctuating evolution of the incomes and expenditures of the City Hall, and also shows a fluctuating patrimonial result with surplus or deficit. In the last years we observe the increase of Income from taxes, fees, contributions, insurance and other income of budgets and a decrease of Funding, subsidies and transfers.

Considering the annual data from the Annex 3 and 4 for City Hall, the data can be centralized in the account 521.02.00.02.A. as follows:

- take over the balance of revenue (receipts) accounts

- take over payments of subordinate institutions

- taking over finance accounts (payments made)

Circulation
521.02.00.02.A.

$\mathrm{D}$ $5,319,650.61$

$5,319,650.61$ $661,284.23$

$\begin{aligned} & \mathrm{C} \\ & 2,012,577.64 \\ & 2,645,788.74 \\ & 4,658,366.38\end{aligned}$

The result of the budget execution in the current year is 661,284.23 lei representing the liquidities with which the institution has finished the financial year.

\section{Conclusions}

Considering the fact that the accrual accounting is used for the establishment of the patrimonial result, the patrimonial surplus or deficit brings changes in the net assets, respectively in the liquidities accounts, but also the incomes not cashed in the current year influence the budget executions in the coming years.

Also, the use of the budget surplus from previous years in the current year can bring increases in the value of net assets and a deficit in the patrimonial result. So, we think that the financial performance of a public institution can be expressed only by the simple difference between income and expenditure (patrimonial result) and not by looking for a correlation between surplus / deficit and patrimony items.

\section{References}

1. Abăluţă, O. (2004). Importanţa productivităţii în sectorul public, Administraţie şi management public, no. 2, pp. 108-113.

2. Bărbulescu, C., Bâgu, C. (2001). Managementul producţiei, vol. II - Politici manageriale de producţie, Tribuna Economică, Bucharest.

3. Bărbuță-Mișu, N. (2009). Finanțarea și performanța întreprinderii, Didactică și Pedagogică, Bucharest.

4. Behn, R. D. (2003). Why Measure Performance? Different Purposes Require Different Measures, Public Administration Review, vol. 63, no. 5, pp. 586-606.

5. Bistriceanu, Gh. (2001). Lexicon de finanţe, bănci, asigurări, vol. II, III, Economică, Bucharest. 
6. Bourguignon, A. (1995). Peut-on définir la Performance?, Revue Française de Comptabilité.

7. Buşe, L. (2005). Analiză economico-financiară, Economică, Bucharest.

8. Cardoş, B. M., Muţ, M. E. (2012). Models of organizational performance measurement, Review of Management \& Economic Engineering, vol. 11, no. 3, pp. 157-168.

9. Chiriac, S. C. V. (2014). The performance of a company - financial-accounting approach, Management Intercultural, vol. XVI, no. 2 (31), pp. 77-82.

10. Colasse, B. (1999). Analyse financière d’entreprise, La Découverte, Paris.

11. Dumitraşcu, R. A., Dumitraşcu, V. (2003). Managementul performanţelor financiare. Concepte. Modele. Instrumente, Universitară, Bucharest.

12. Hada, T. (2010). Gestiunea financiară a întreprinderii, Ediţia a II-a actualizată şi completată, Aeternitas, Alba Iulia.

13. Handler, H., Koebel, B., Reiss, P., Schratzenstaller, M. (2005). The Size and Performance of Public Sector Activities in Europe (February 2005), WIFO Working paper No. 246/2005, available at http://papers.ssrn.com/sol3/papers.cfm?abstract_id=1861528, accesed at 16.01.2017.

14. Jianu, I. (2007). Evaluarea, prezentarea şi analiza performanţei întreprinderii. $O$ abordare din prisma Standardelor Internaţionale de Raportare Financiară, CECCAR, Bucharest.

15. Likierman, A. (1993). Performance Indicators: 20 Early Lessons from Managerial Use, Public Money and Management, vol. 13, no. 4, pp. 15-22.

16. Mateş, D., Matiş, D., Coleţ, D. (2006). Contabilitatea financiară a entităţilor economice, Mirton, Timişoara.

17. Mihaiu, D. (2014). Measuring performance in the public sector: between necessity and difficulty, Studies in Business and Economics, Lucian Blaga University of Sibiu, Romania.

18. Morariu, A., Suciu, Gh. (2004). Contabilitatea instituţiilor publice, Universitară, Bucharest.

19. Niculescu, M. (2003). Diagnostic global strategic, Economică, Bucharest.

20. Noyer, D. (2002). Manager les performances, Insep Consulting Editions, Paris.

21. Pintea, M. O. (2011). Performanţa entităţilor economice în contextul dezvoltării durabile, Risoprint, Cluj Napoca.

22. Profiroiu, A., Profiroiu, M. (2007). Cadrul de analiză a performanţelor sectorului public, Economie Teoretica şi Aplicată, vol. 1 (506), pp. 41-50.

23. Raduti, A. (2003). Contabilitate publică, Economică, Bucharest.

24. Smith, R. (1983). Japanese Society: Tradition, Self and the Social Order, New York, Cambridge University Press.

25. Tabără, N., Dicu, R. M. (2007). Indicatorii de performanţă în contextul reglementărilor contabile internaţionale, EIRP Proceedings, Danubius University, vol. 2, pp. 368-374.

26. Sava, S. (1998). Dicţionar Macmillan de Economie Modernă, CODECS, Bucharest.

27. Smith, P. (1990). The Use of Performance Indicators in the Public Sector, Journal of the Royal Statistical Society, Series A (Statistics in Society), vol. 153, part 1, pp. 5372.

28. Stroe, R., Bărbuță-Mișu, N. (2008). Finanțarea și gestiunea financiară a intreprinderii - Aplicații și studii de caz, Didactică și Pedagogică, R.A, Bucharest.

29. Ştefănescu, A., Dobrin, C., Calu, D. A., Țurlea, E. (2010). Controverse privind măsurarea performanţelor entităţilor administraţiei publice din România, Revista Transilvană de Ştiinţe Administrative, vol. 1, no. 25, pp. 225-242. 
30. Ştefănescu, A., Dobrin, C., Calu, D. A., Ţurlea, E. (2010). Abordări privind rolul performanţei în entităţile sectorului public din România, Revista Anale. Seria Ştiinţe Economice, Timişoara, vol. 16, pp. 193-196.

31. Tripon, C., Dodu, M., Raboca, H. (2011). Managementul resurselor umane, BabeşBolyai University of Cluj-Napoca, available at http://www.apubb.ro/wpcontent/uploads/2011/03/Managementul_resurselor_umane.pdf, accessed at 16.01.2017. 
Annex 1. Groups of expenses and incomes

\begin{tabular}{|l|l|c|l|}
\hline Code & \multicolumn{1}{|c|}{ Expenses } & & \multicolumn{1}{|c|}{ Incomes } \\
\hline 60 & Expenditure on inventories & 70 & Income from economic activities \\
\hline 61 & $\begin{array}{l}\text { Expenditure on works and services } \\
\text { performed by third parties }\end{array}$ & 71 & Other operating income \\
\hline 62 & $\begin{array}{l}\text { Expenses with other services } \\
\text { performed by third parties }\end{array}$ & 72 & Income from fixed asset production \\
\hline 63 & $\begin{array}{l}\text { Expenses with other taxes, fees and } \\
\text { similar payments }\end{array}$ & 73 & Tax revenue \\
\hline 64 & Staff costs & 74 & Income from insurance contributions \\
\hline 65 & Other operational expenditure & 75 & Non-tax revenues \\
\hline 66 & Financial expenses & 76 & Financial income \\
\hline 67 & $\begin{array}{l}\text { Other expenditure financed from the } \\
\text { budget }\end{array}$ & 77 & $\begin{array}{l}\text { Grants, subsidies, transfers, special } \\
\text { budget allocations, special purpose } \\
\text { funds }\end{array}$ \\
\hline 68 & $\begin{array}{l}\text { Expenses with depreciation, } \\
\text { provisions and adjustments for } \\
\text { depreciation or impairment losses }\end{array}$ & 78 & $\begin{array}{l}\text { Income from provisions and } \\
\text { adjustments for depreciation or } \\
\text { impairment losses }\end{array}$ \\
\hline 69 & Extraordinary expenses & 79 & Extraordinary revenue \\
\hline
\end{tabular}

Annex 2. Closure of income and expense accounts

$$
\% \quad=\quad 121.00 .00 .02 . \mathrm{A} \cdot \mathrm{A} 02
$$

$1,322,978.28$

$1,190.43$

$-1,190.43$

$21,792.50$

$12,170.00$

9.18

837.40

$3,929.82$

$3,709.04$

$292,000.00$

$633,215.00$

$22,571.48$

443.53

$-9,373.29$

23,084.07

$20,185.66$

$10,334.72$

$8,063.41$

$7,530.00$

$193,000.00$

$79,475.76$

682,127.81

$1,614.63$ 
681.01.00.02.A.84020301.710102

$25,906.47$

681.01.00.02.A.83020330.710130

$2,165.70$

681.01.00.02.A.680206.710102

$1,118.37$

681.01.00.02.A.67020307.710103

102.27

681.01.00.02.A.51020103.710130

286.90

681.01.00.02.A.51020103.710103

$17,707.17$

681.01.00.02.A.51020103.710102

$2,635.11$

681.01.00.02.A.51020103.710101

$6,585.06$

679.00.00.02.A.680206.550118

$-5,534.00$

679.00.00.02.A.51020103.5911

$10,210.00$

677.00.00.02.A.68021501.570201

$11,890.00$

677.00.00.02.A.68020502.570201

$66,861.00$

677.00.00.02.A.650250.570203

$1,000.00$

645.05.00.02.A.870204.100306

37.00

645.05.00.02.A.84020301.100306

66.00

645.05.00.02.A.700206.100306

66.00

645.05.00.02.A.68020502.100306

206.00

645.05.00.02.A.67020307.100306

15.00

645.05.00.02.A.67020302.100306

38.00

645.05.00.02.A.66025050.100306

33.00

645.05.00.02.A.51020103.100306

934.00

645.04.00.02.A.870204.100304

6.00

645.04.00.02.A.84020301.100304

12.00

645.04.00.02.A.700206.100304

12.00

645.04.00.02.A.68020502.100304

36.00

645.04.00.02.A.67020307.100304

3.00

645.04.00.02.A.67020302.100304

6.00

645.04.00.02.A.66025050.100304

6.00

645.04.00.02.A.51020103.100304

165.00

645.03.00.02.A.870204.100303

229.00

645.03.00.02.A.84020301.100303

405.00

645.03.00.02.A.700206.100303

405.00

645.03.00.02.A.68020502.100303

$1,259.00$

645.03.00.02.A.67020307.100303

102.00

645.03.00.02.A.67020302.100303

232.00

645.03.00.02.A.66025050.100303

204.00

645.03.00.02.A.51020103.100303

$5,711.00$

645.02.00.02.A.870204.100302

21.00

645.02.00.02.A.84020301.100302

39.00

645.02.00.02.A.700206.100302

39.00

645.02.00.02.A.68020502.100302

121.00

645.02.00.02.A.67020307.100302

9.00

645.02.00.02.A.67020302.100302

23.00 
645.02.00.02.A.66025050.100302

21.00 645.02.00.02.A.51020103.100302

548.00 645.01.00.02.A.870204.100301 697.00 645.01.00.02.A.84020301.100301 $1,227.00$ 645.01.00.02.A.700206.100301 $1,227.00$ 645.01.00.02.A.68020502.100301 645.01.00.02.A.67020307.100301 $3,826.00$ 645.01.00.02.A.67020302.100301 306.00 706.00 645.01.00.02.A.66025050.100301 621.00 645.01.00.02.A.51020103.100301 $17,290.00$ 641.00.00.02.A.870204.100106 528.00 641.00.00.02.A.870204.100101 $3,882.00$ 641.00.00.02.A.84020301.100101 $7,764.00$ 641.00.00.02.A.700206.100101 $7,764.00$ 641.00.00.02.A.68020502.100101 $24,216.00$ 641.00.00.02.A.67020307.100101 $1,941.00$ 641.00.00.02.A.67020302.100101 $4,470.00$ 641.00.00.02.A.66025050.100101 $3,939.00$ 641.00.00.02.A.51020103.100112 $8,311.00$ 641.00.00.02.A.51020103.100101 $101,153.00$ 629.01.00.02.A.51020103.200130 $64,373.99$ 628.00.00.02.A.870204.200130 $12,000.00$ 628.00.00.02.A.84020301.200130 $1,434.37$ 628.00.00.02.A.700206.2002 $9,596.76$ 628.00.00.02.A.51020103.200130 $16,155.56$ 626.00.00.02.A.51020103.200108 $5,783.90$ 614.00.00.02.A.51020103.200601 $2,658.00$ 611.00.00.02.A.84020301.2002 611.00.00.02.A.51020103.2002 $138,040.56$ 300.00 610.00.00.02.A.700206.200103 610.00.00.02.A.67020307.200104 $19,735.36$ 864.56 610.00.00.02.A.67020307.200103 569.06 610.00.00.02.A.51020103.200104 $8,964.57$ 610.00.00.02.A.51020103.200103 $14,317.51$ 602.08.00.02.A.51020103.2011 $2,979.69$ 602.08.00.02.A.51020103.200109 $22,138.94$ 602.08.00.02.A.51020103.200101 $5,993.50$ 602.02.00.02.A.84020301.200105 $9,400.45$ 602.02.00.02.A.51020103.200105 


\section{Annex 3. Closing the account 521.01.00}

521.02.00.02.A. „Result of budget execution of the current year"

$$
=\%
$$

521.01.00.02.A.070203

521.01.00.02.A.07020203

521.01.00.02.A.07020202

521.01.00.02.A.07020201

521.01.00.02.A.07020102

521.01.00.02.A.07020101

521.01.00.02.A.040204

521.01.00.02.A.430234

521.01.00.02.A.430230

521.01.00.02.A.420265

521.01.00.02.A.420241

521.01.00.02.A.420234

521.01.00.02.A.390207

521.01.00.02.A.370204

521.01.00.02.A.370203

521.01.00.02.A.35020102

521.01.00.02.A.040201

521.01.00.02.A.300250

521.01.00.02.A.30020530

521.01.00.02.A.300201

521.01.00.02.A. 180250

521.01.00.02.A.160203

521.01.00.02.A.16020202

521.01.00.02.A.16020201

521.01.00.02.A.110206

521.01.00.02.A.110202

521.01.00.02.A.070250

521.01.00.02.A.030218
$5,319,650.61$

$4,300.87$

$179,197.45$

$28,267.00$

$99,727.00$

$65,501.00$

$124,270.00$

$835,000.00$

$7,680.00$

$10,604.80$

$299,080.31$

$19,219.00$

$2,848.00$

$87,733.19$

$26,190.43$

$-26,190.43$

$58,492.50$

$369,373.66$

$105,400.00$

$159,827.74$

$45,117.72$

52.00

$1,599.41$

$14,287.80$

$112,314.06$

$610,000.00$

$1,995,925.00$

$61,666.10$

$22,166.00$

Annex 4. The closure of the account 770

770.00.00.02.A.870204.200130 $=\quad 521.02 .00 .02 . \mathrm{A}$.

770.00.00.02.A.870204.100306

$\mathbf{2 , 6 4 5 , 7 8 8 . 7 4}$

$48,000.00$

76.00

24.00

910.00

770.00.00.02.A.870204.100303

84.00

770.00.00.02.A.870204.100302

$2,771.00$

353.00

770.00.00.02.A.870204.100106

$17,190.00$

770.00.00.02.A.870204.100101

$25,000.00$

770.00.00.02.A.84020301.710130

$259,311.86$ 
770.00.00.02.A.84020301.200130

$113,556.71$

770.00.00.02.A.84020301.200105

$28,591.25$

770.00.00.02.A.84020301.100306

132.00

770.00.00.02.A.84020301.100304

48.00

770.00.00.02.A.84020301.100303

770.00.00.02.A.84020301.100302

$1,607.00$

155.00

770.00.00.02.A.84020301.100301

$4,869.00$

770.00.00.02.A.84020301.100101

$30,810.00$

770.00.00.02.A.83020330.710130

$38,982.75$

770.00.00.02.A.83020330.100306

40.00

770.00.00.02.A.83020330.100304

19.00

770.00.00.02.A.83020330.100303

629.00

770.00.00.02.A.83020330.100302

57.00

770.00.00.02.A.83020330.100301

$1,943.00$

770.00.00.02.A.83020330.100101

$12,269.00$

770.00.00.02.A.700206.2002

$19,827.76$

770.00.00.02.A.700206.200103

$97,489.17$

770.00.00.02.A.700206.100306

770.00.00.02.A.700206.100304

770.00.00.02.A.700206.100303

770.00.00.02.A.700206. 100302

770.00.00.02.A.700206.100301

770.00.00.02.A.700206.100101

132.00

48.00

$1,583.00$

152.00

$4,903.00$

$30,820.00$

770.00.00.02.A.70020501.710130

$2,916.87$

770.00.00.02.A.70020501.710101

$299,080.31$

770.00.00.02.A.68021501.570201

$12,094.00$

770.00.00.02.A.68020502.570201

$257,130.00$

248.00

770.00.00.02.A.68020502.100306

76.00

$770.00 .00 .02 . A .68020502 .100304$

$2,559.00$

247.00

770.00.00.02.A.68020502.100302

$7,777.00$

770.00.00.02.A.68020502.100301

$52,922.00$

770.00.00.02.A.68020502.100101

$20,000.00$

770.00.00.02.A.670206.5912

$19,094.09$

770.00.00.02.A.67020307.200104

$4,697.09$

770.00.00.02.A.67020307.200103

$6,085.12$

30.00

12.00

770.00.00.02.A.67020307.100304

408.00

36.00

770.00.00.02.A.67020307.100302

$1,224.00$

770.00.00.02.A.67020307.100301

$7,764.00$

77.00

35.00

770.00.00.02.A.67020302.100304

609.00 
770.00.00.02.A.67020302.100302

62.00

770.00.00.02.A.67020302.100301

$2,653.00$

770.00.00.02.A.67020302.100101

$16,261.00$

770.00.00.02.A.66025050.100306

66.00

770.00.00.02.A.66025050.100304

24.00

770.00.00.02.A.66025050.100303

816.00

770.00.00.02.A.66025050.100302

84.00

770.00.00.02.A.66025050.100301

$2,484.00$

770.00.00.02.A.66025050.100101

$15,745.00$

770.00.00.02.A.650250.710101

$17,900.00$

770.00.00.02.A.650250.580402

$24,270.00$

770.00.00.02.A.650250.580401

770.00.00.02.A.650250.570203

$4,854.00$

770.00.00.02.A.540250.200130

$4,200.00$

770.00.00.02.A.51020103.5911

$7,852.52$

770.00.00.02.A.51020103.2013

$14,030.00$

$9,040.00$

770.00.00.02.A.51020103.2011

$2,979.69$

770.00.00.02.A.51020103.200601

$5,920.00$

770.00.00.02.A.51020103.200530

$31,806.68$

770.00.00.02.A.51020103.2002

$137,606.84$

770.00.00.02.A.51020103.200130

$260,021.22$

770.00.00.02.A.51020103.200109

$51,618.63$

770.00.00.02.A.51020103.200108

$23,527.94$

770.00.00.02.A.51020103.200105

$12,503.95$

770.00.00.02.A.51020103.200104

$34,577.29$

770.00.00.02.A.51020103.200103

$26,801.58$

770.00.00.02.A.51020103.200101

$18,137.42$

770.00.00.02.A.51020103.100306

$1,608.00$

770.00.00.02.A.51020103.100304

580.00

770.00.00.02.A.51020103.100303

$20,463.00$

770.00.00.02.A.51020103.100302

$1,936.00$

770.00.00.02.A.51020103.100301

$61,285.00$

770.00.00.02.A.51020103.100112

$27,520.00$

770.00.00.02.A.51020103.100101

$369,049.00$

Annex 5. Account of Patrimonial result in the period 2012-2016

\begin{tabular}{|c|c|c|c|c|c|c|c|}
\hline No. & Name of the indicator & $\begin{array}{l}\text { Raw } \\
\text { code }\end{array}$ & 2016 & 2015 & 2014 & 2013 & 2012 \\
\hline $\mathbf{A}$ & B & $\mathbf{C}$ & 1 & 2 & 3 & 3 & 5 \\
\hline I. & OPERATING INCOME & 01 & & & & & \\
\hline 1. & $\begin{array}{l}\text { Income from taxes, fees, contributions, insurance and } \\
\text { other income of budgets } \\
\text { (ct. } 7300100+7300200+7310100+7310200+7320100+ \\
7330000+7340000+7350100+7350200+7350300+ \\
7350400+7350500+7350600+7360100+7390000+ \\
7450100+7450200+7450300+7450400+7450500+ \\
7450900+7460100+7460200+7460300+7460900)\end{array}$ & 02 & $4,815,792.00$ & $3,903,966.00$ & $4,162,145.00$ & $3,042,405.00$ & $3,071,029.00$ \\
\hline 2. & $\begin{array}{l}\text { Income from economic activities } \\
(\text { ct. } 7210000+7220000+7510100+7510200+/-7090000)\end{array}$ & 03 & $45,450.00$ & $22,193.00$ & $47,435.00$ & $336,334.00$ & $225,658.00$ \\
\hline 3. & $\begin{array}{l}\text { Funding, subsidies, transfers } \\
\text { (ct. } 7510500+7710000+7720100+7720200+7740100+ \\
7740200+7750000+7760000+7780000+7790101+ \\
7790109)\end{array}$ & 04 & $397,855.00$ & $2,155,564.00$ & $1,696,098.00$ & $10,399,122.00$ & $7,429,519.00$ \\
\hline 4. & Other operating revenues & 05 & $404,511.00$ & $264,518.00$ & $542,747.00$ & $432,519.00$ & $286,406.00$ \\
\hline
\end{tabular}




\begin{tabular}{|c|c|c|c|c|c|c|c|}
\hline & $\begin{array}{l}\text { (ct. } 7140000+7180000+7500000+7510300+7510400+ \\
7810200+7810300+7810401+7810402+7770000)\end{array}$ & & & & & & \\
\hline & TOTAL OPERATING INCOME (rd.02+03+04+05) & 06 & $5,663,608.00$ & $6,346,241.00$ & $6,448,425.00$ & $14,210,380.00$ & $11,012,612.00$ \\
\hline II. & OPERATING EXPENDITURE & 07 & & & & & \\
\hline 1. & $\begin{array}{l}\text { Salaries and social contributions related to employees } \\
\text { (ct. } 6410000+6420000+6450100+6450200+6450300+ \\
6450400+450500+6450600+6450800+6460000+ \\
6470000)\end{array}$ & 08 & $2,465,834.00$ & $2,104,860.00$ & $1,677,604.00$ & $1,560,692.00$ & $1,421,153.00$ \\
\hline 2. & $\begin{array}{l}\text { Subsidies and transfers } \\
\text { (ct. } 6700000+6710000+6720000+6730000+6740000+ \\
6750000+6760000+6770000+6780000+6790000)\end{array}$ & 09 & $368,369.00$ & $523,441.00$ & $567,300.00$ & $388,133.00$ & $436,637.00$ \\
\hline 3. & $\begin{array}{l}\text { Inventories, consumables, works and services performed } \\
\text { by third parties } \\
(\text { ct. } 6010000+6020100+6020200+6020300+6020400+ \\
6020500+6020600+6020700+6020800+6020900+6030000+ \\
6060000+6070000+6080000+6090000+6100000+6110000+ \\
6120000+6130000+6140000+6220000+6230000+6240100+ \\
6240200+6260000+6270000+6280000+6290100)\end{array}$ & 10 & $1,735,933.00$ & $204,972.00$ & $1,688,103.00$ & $1,776,258.00$ & $1,596,828.00$ \\
\hline 4. & $\begin{array}{l}\text { Capital expenditures, depreciation and provisions (ct. } \\
6290200+6810100+6810200+6810300+6810401+6810402+ \\
6820101+6820109+6820200+6890100+6890200)\end{array}$ & 11 & $3,911,023.00$ & $33,089.00$ & $43,532.00$ & $11,488,321.00$ & $5,963,426.00$ \\
\hline \multirow[t]{2}{*}{5.} & $\begin{array}{l}\text { Other operating expenses } \\
(\text { ct. } 6350000+6540000+6580101+6580109)\end{array}$ & 12 & & & & & \\
\hline & 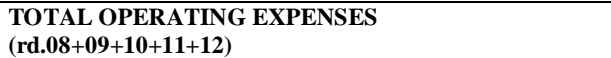 & 13 & $8,481,159.00$ & $4,666,362.00$ & $3,976,539.00$ & $15,213,404.00$ & $9,418,044.00$ \\
\hline \multirow[t]{3}{*}{ III. } & OPERATING RESULT & 14 & & & & & \\
\hline & - SURPLUS (rd.06- rd.13) & 15 & & $1,679,879.00$ & $2,471,886.00$ & & $1,594,568.00$ \\
\hline & - DEFICIT (rd.13- rd.06) & 16 & $2,817,551.00$ & & & $1,003,024.00$ & \\
\hline IV. & $\begin{array}{l}\text { FINANCIAL INCOME } \\
\text { (ct. } 7630000+7640000+7650100+7650200+7660000+ \\
7670000+7680000+7690000+7860300+7860400)\end{array}$ & 17 & & & & & \\
\hline V. & $\begin{array}{l}\text { FINANCIAL EXPENDITURE } \\
\text { (ct. } 6630000+6640000+6650100+6650200+6660000+ \\
6670000+6680000+6690000+6860300+6860400+6860800)\end{array}$ & 18 & & & & $55,186.00$ & \\
\hline \multirow[t]{3}{*}{ VI. } & FINANCIAL RESULT & 19 & & & & & \\
\hline & - SURPLUS (rd.17- rd.18) & 20 & & & & & \\
\hline & - DEFICIT (rd.18- rd.17) & 21 & & & & $55,186.00$ & \\
\hline \multirow[t]{3}{*}{ VII. } & RESULT FROM CURRENT ACTIVITY & 22 & & & & & \\
\hline & - SURPLUS (rd.15+20-16-21) & 23 & & $1,679,879.00$ & $2,471,886.00$ & & $1,594,568.00$ \\
\hline & - DEFICIT (rd.16+21-15-20) & 24 & $2,817,551.00$ & & & $1,058,210.00$ & \\
\hline VIII. & $\begin{array}{l}\text { EXTRAORDINARY INCOME } \\
\text { (ct.7910000) }\end{array}$ & 25 & $87,733.00$ & $4,778.00$ & $4,312.00$ & $4,468.00$ & \\
\hline IX. & $\begin{array}{l}\text { EXTRAORDINARY EXPENDITURE } \\
\text { (ct.6900000+6910000) }\end{array}$ & 26 & & & & & \\
\hline \multirow[t]{3}{*}{$\mathbf{X}}$. & EXTRAORDINARY RESULT & 27 & & & & & \\
\hline & - SURPLUS (rd.25-rd.26) & 28 & $87,733.00$ & $4,778.00$ & $4,312.00$ & $4,468.00$ & \\
\hline & - DEFICIT (rd.26-rd.25) & 29 & & & & & \\
\hline \multirow[t]{3}{*}{ XI. } & $\begin{array}{l}\text { PATRIMONIAL RESULT OF THE FINANCIAL } \\
\text { EXERCISE }\end{array}$ & 30 & & & & & \\
\hline & - SURPLUS (rd. 23+28-24-29) & 31 & & $1,684,657.00$ & $2,476,198.00$ & & $1,594,568.00$ \\
\hline & - DEFICIT (rd. 24+29-23-28) & 32 & $2,729,818.00$ & & & $1,053,742.00$ & \\
\hline
\end{tabular}

